
ISSN : 2615-1995, E-ISSN : 2615-0654

J. Madani., Vol. 1, No. 1, Maret 2018 (267-286)

(C)2018 Lembaga Kajian Demokrasi

MADAN

dan Pemberdayaan Masyarakat (LKD-PM)

\title{
ANALISIS PENGARUH KOMPENSASI, BUDAYA ORGANISASI DAN MOTIVASI TERHADAP KINERJA PEGAWAI \\ Pada Perusahaan Daerah Air Minum Tirta Kerta Raharja Kabupaten Tangerang
}

\author{
Udin Saprudin \\ Fakultas Ekonomi, Universitas Pamulang \\ Email : dinsunpam17@gmail.com
}

\begin{abstract}
ABSTRAK
Tujuan dilakukannya penelitian ini adalah Untuk mengetahui seberapa besar pengaruh kompensasi terhadap kinerja pegawai; Untuk mengetahui seberapa besar pengaruh budaya organisasi terhadap kinerja pegawai; Untuk mengetahui seberapa besar pengaruh motivasi terhadap kinerja pegawai; Untuk mengetahui seberapa besar pengaruh kompensasi, budaya organisasi, motivasi secara simultan terhadap kinerja pegawai. Analisis Pengaruh Kompensasi, Budaya Organisasi dan Motivasi terhadap Kinerja Pegawai Pada Perusahaan Daerah Air MinumTirta Kerta Raharja Kabupaten TangerangTujuan penelitian untuk mengetahui fenomena, serta kesimpulan mengenai pengaruh ketiga variable bebas terhadap kinerja di Perusahaan Daerah Air MinumTirta Kerta Raharja Kabupaten Tangerang. Teknik analisis data yang digunakan dalam penelitian ini yaitu: uji kualitas data validitas dan reliabilitas, analisis deskriptif, uji asumsi klasik normalitas, multikolinieritas, heterokendatisitas dan autokorelasi, analisis regresi yaitu regresi sederhana dan berganda, parsial $t$, simultan $F$ dan koefesien determinasi. Pengambilan sampel menggunakan rumus Slovin dengan tingkat eror 0.05, responden dalam penelitian ini 193 (seratus sembilan puluh tiga)pegawai Perusahaan Daerah Air MinumTirta Kerta Raharja Kabupaten Tangerang.Hasil penelitian sebagai berikut : hasil uji parsial t pertama menjawab HO ditolak dan H1 diterima yaitu terdapat pengaruh Kompensasi terhadap Kinerja. Hasil uji parsial t kedua menjawab HO ditolak dan H2 diterima yaitu terdapat pengaruh Budaya Organisasi terhadap Kinerja. Hasil uji parsial ketiga menjawab Ho ditolak. H3 diterima yaitu terdapat pengaruh Motivasi terhadap Kinerja dan Hasil uji simultan F menjawab Ho ditolak dan H4 diterima yaitu terdapat pengaruh secara bersama-sama Kompensasi, Budaya Organisasi dan Motivasi terhadap Kinerja Pegawai Pada Perusahaan Daerah Air MinumTirta Kerta Raharja Kabupaten Tangerang.
\end{abstract}

Kata Kunci : Kompensasi, Budaya Organisasi, Motivasi, Kinerja 


\section{PENDAHULUAN}

\section{Latar Belakang}

Perusahaan Daerah Air Minum Tirta Kerta Raharja Kabupaten Tangerang Badan Usaha Milik Daerah (BUMD) milik Pemerintah Kabupaten Tangerang memiliki jumlah sambungan langganan +128.000 yang melayani daerah Kabupaten Tangerang, Kota Tangerang, Kota Tangerang Selatan dan DKI Jakarta dengan jumlah pegawai 373 orang. Melaksanakan kegiatan perusahaan dengan tujuan melayani masyarakat melalui jalur perpipaan dan non perpipaan sehingga masyarakat dapat terlayani oleh akses air bersih yang disalurkan oleh Perusahaan Daerah Air Minum Tirta Kerta Raharja Kabupaten Tangerang, disamping mencari profit untuk memberikan kontribusi pendapatan asli daerah (PAD) diamanatkan oleh Peraturan daerah Kabupaten Tangerang nomor : 7 Tahun 2001 Perusahaan Daerah Air Minum Tirta Kerta Raharja Kabupaten ada fungsi sosial untuk mensejahtrakan masyarakat.

Dalam menjalankan organisasi perusahaan penyediaan air bersih Perusahaan Daerah Air Minum Tirta Kerta Raharja Kabupaten di tunjang oleh kualitas sumber daya manusia dari berbagai macam latar belakang pendidikan yang berbeda-beda, teknik dan non teknik. Kondisi Sumber Daya Manusia Perusahaan Daerah Air Minum Tirta Kerta Raharja Kabupaten Tangerang per bulan Desember 2015 berjumlah 373 pegawai.
Tabel.1.1

Data Pegawai PDAM Tirta Kerta Raharja

Kabupaten Tangeran

\begin{tabular}{|c|c|c|}
\hline No & Uraian & $\begin{array}{l}\text { Jumlah } \\
\text { Pegawai }\end{array}$ \\
\hline I. & $\begin{array}{cl}\text { Berdasarkan Status Pegawai } \\
\text { a. } & \text { Pegawai Tetap } \\
\text { b. } & \text { Calon Pegawai } \\
\text { c. } & \text { Pegawai Kontrak }\end{array}$ & $\begin{array}{l}337 \text { orang } \\
1 \text { orang } \\
35 \text { orang }\end{array}$ \\
\hline II. & $\begin{array}{l}\text { Berdasarkan Unit Kerja } \\
\text { a. Direksi } \\
\text { b. Satuan } \\
\text { c. Staf Ahli } \\
\text { d. Direktorat Umum } \\
\text { e. Direktorat Teknik } \\
\text { f. Wilayah /Cabang/IKK } \\
\text { h. Koperasi }\end{array}$ & $\begin{array}{l}3 \text { orang } \\
42 \text { orang } \\
1 \text { orang } \\
56 \text { orang } \\
49 \text { orang } \\
219 \text { orang } \\
3 \text { orang }\end{array}$ \\
\hline III. & $\begin{array}{l}\text { Berdasarkan Jenis Kelamin } \\
\text { a. Laki - laki } \\
\text { b. Perempuan }\end{array}$ & $\begin{array}{l}316 \text { orang } \\
57 \text { orang }\end{array}$ \\
\hline IV. & $\begin{array}{cl}\text { Berdasarkan Status Perkawinan } \\
\begin{array}{cl}\text { a. } & \text { Menikah } \\
\text { b. } & \text { Duda/Janda } \\
\text { c. } & \text { Belum Menikah }\end{array}\end{array}$ & $\begin{array}{l}352 \text { orang } \\
7 \text { orang } \\
14 \text { orang }\end{array}$ \\
\hline V. & $\begin{array}{l}\text { Berdasarkan Tingkat Pendidikan } \\
\text { a. SLTA } \\
\text { c. D. III } \\
\text { d. S.1 } \\
\text { f. S.2 }\end{array}$ & $\begin{array}{l}282 \text { orang } \\
16 \text { orang } \\
61 \text { orang } \\
14 \text { orang }\end{array}$ \\
\hline VI. & $\begin{array}{l}\text { Berdasarkan Status Jabatan } \\
\text { a. Direksi } \\
\text { b. Kepala Satuan } \\
\text { c. Staf. Ahli } \\
\text { d. Kabag / Kabid / Inspektorat } \\
\text { e. Kasubag / Ka.Sie / Ka.Sub.Bid / } \\
\text { Insp. Pembantu } \\
\text { f. Staf }\end{array}$ & $\begin{array}{l}3 \text { orang } \\
4 \text { orang } \\
1 \text { orang } \\
25 \text { orang } \\
68 \text { orang } \\
272 \text { orang }\end{array}$ \\
\hline
\end{tabular}


Tabel 1.2

Unit Kerja

\begin{tabular}{|c|l|c|c|}
\multirow{2}{*}{ No } & \multirow{2}{*}{ Unit Kerja } & \multicolumn{2}{c|}{ Keterangan } \\
\cline { 3 - 4 } & & Jumlah & Presentase \\
\hline 1 & Staf Ahli Direksi & 2 & $1 \%$ \\
\hline 2 & Satuan Sekertaris Perusahaan & 9 & $4 \%$ \\
\hline 3 & Satuan Pengawas Internal (SPI) & 5 & $3 \%$ \\
\hline 4 & Penelitian dan Pengembangan & 7 & $4 \%$ \\
\hline 5 & Air Curah & 4 & $2 \%$ \\
\hline 6 & Pimpro & 6 & $3 \%$ \\
\hline 7 & Keuangan & 9 & $5 \%$ \\
\hline 8 & Pelayanan Pelangan & 9 & $5 \%$ \\
\hline 9 & Sistim Informasi Manajemen & 5 & $3 \%$ \\
\hline 10 & Kepegawaian & 7 & $4 \%$ \\
\hline 11 & Rumah Tangga & 10 & $5 \%$ \\
\hline 12 & Produksi & 8 & $4 \%$ \\
\hline 13 & Transmisi dan Distribusi & 10 & $5 \%$ \\
\hline 14 & Perawatan dan Pemeliharaan & 4 & $2 \%$ \\
\hline 15 & Perencanaan & 7 & $4 \%$ \\
\hline 16 & Wilayah Pelayanan I & 8 & $4 \%$ \\
\hline 17 & Wilayah Pelayanan II & 16 & $8 \%$ \\
\hline 18 & Wilayah Pelayanan III & 27 & $14 \%$ \\
\hline 19 & Cabang Serpong & 12 & $6 \%$ \\
\hline 20 & Cabang Teluknaga & 13 & $7 \%$ \\
\hline 21 & Cabang Tigaraksa & 7 & $4 \%$ \\
\hline 22 & Pelayanan IKK & 193 & $100 \%$ \\
\hline & & & \\
\hline
\end{tabular}

Sumber : Observasi Penelitian (2016)

Berdasarkan data yang diperoleh dari observasi penelitian diketahui bahwa jumlah pegawai pada Perusahaan Daerah Air Minum Tirta Kerta Raharja berjumlah 373 pegawai. Hal ini tentu saja sangat berkaitan dengan produktivitas perusahaan tersebut apabila para pegawai memiliki kinerja yang baik. Kinerja pegawai dapat dipengaruhi oleh berbagai faktor.

\section{Identifikasi Masalah}

Sesuai dengan latar belakang penelitian di atas, kami sampaikan sebagai berikut :

1. Gaji, tunjangan-tunjangan dan fasilitas kesehatan yang diberikan Perusahaan Daerah Air Minum Tirta Kerta Raharja Kabupaten Tangerang belum sesuai dengan harapan pegawai;

2. Kordinasi dan komunikasi antar Pegawai
Perusahaan Daerah Air Minum Tirta Kerta Raharja Kabupaten Tangerang belum maksimal;

3. Pendidikan dan pelatihan pegawai Perusahaan Daerah Air Minum Tirta Kerta Raharja Kabupaten Tangerang, masih belum maksimal;

4. Absensi tingkat kehadiran serta apel pagi bagi Pegawai Perusahaan Daerah Air Minum Tirta Kerta Raharja Kabupaten Tangerang, masih belum maksimal di laksanakan.

\section{Pembatasan Masalah}

Berdasarkan masalah penelitian yang diuraikan diatas perlu studi lebih lanjut tentang kinerja pegawai yang dipengaruhi oleh kompensasi, budaya organisasi dan motivasi serta dibatasi dengan 4 (empat) variabel yaitu, Kompensasi (X1) Budaya organisasi (X2) Motivasi (X3) sebagai variabel independen, dan Kinerja Pegawai (Y) sebagai variabel dependen.

1. Dimaksud dengan kompensasi adalah segala sesuatu yang diterima karyawan/pegawai. sebagai balas jasa untuk kerja mereka.

2. Dimaksud budaya organisasi adalah pola dasar yang diterima oleh organisasi untuk bertindak dan memecahkan masalah, membentuk karyawan/pegawai yang mampu beradaptasi dengan lingkungan dan mempersatukan anggota-anggota organisasi.

3. Dimaksud dengan Motivasi kerja, sebagai suatu kecenderungan untuk beraktivitas dan dimulai dorongan dalam diri sendiri dan diakhiri dengan penyesuai diri.

4. Dimaksud kinerja pegawai adalah hasil karya secara kualitas dan kuantitas yang dicapai oleh seseorang pegawai dalam melaksanakan tugasnya sesuai dengan tanggung jawab yang diberikan kepadanya.

5. Adapun objek penelitian ini adalah Perusahaan Daerah Air Minum Tirta Kerta Raharja Kabupaten Tangerang, Jalan Kisamaun No. 204 Tangerang - Banten. 


\section{Perumusan Masalah}

1. Seberapa besar pengaruh kompensasi terhadap kinerja Pegawai Perusahaan Daerah Air Minum Tirta Kerta Raharja Kabupaten Tangerang?

2. Seberapa besar pengaruh budaya organisasi terhadap kinerja Pegawai Perusahaan Daerah Air Minum Tirta Kerta Raharja Kabupaten Tangerang?

3. Seberapa besar pengaruh motivasi terhadap kinerja Pegawai Perusahaan Daerah Air Minum Tirta Kerta Raharja Kabupaten Tangerang?

4. Seberapa besar pengaruh kompensasi, budaya organisasi dan motivasi secara simultan terhadap kinerja pegawai Perusahaan Daerah Air Minum Tirta Kerta Raharja Kabupaten Tangerang?

\section{Tujuan Penelitian}

1. Untuk mengetahui seberapa besar pengaruh kompensasi terhadap kinerja pegawai;

2. Untuk mengetahui seberapa besar pengaruh budaya organisasi terhadap kinerja pegawai;

3. Untuk mengetahui seberapa besar pengaruh motivasi terhadap kinerja pegawai;

4. Untuk mengetahui seberapa besar pengaruh kompensasi, budaya organisasi, motivasi secara simultan terhadap kinerja pegawai.

\section{Kajian Teoritis}

\section{Kompensasi}

Menurut T. Hani Handoko (2013:155), “ Kompensasi adalah segala sesuatu yang diterima karyawan sebagai balas jasa untuk kerja mereka " apabila kompensasi diberikan secara benar, kepada karyawan akan lebih terpuaskan dan termotivasi untuk mencapai sasaran - sasaran organisasi sehingga kinerja perusahaan meningkat. Kompnsasi penting bagi karyawan sebagai individu karena besarnya kompensasi mencerminkan ukuran nilai kinerja meraka tingkat kompensasi absolute karyawan menentukan skala kehidupannya, sedangkan kom- pensasi relatif menunjukan status martabat dan harga diri olah karena itu karyawan memandang kompensasi tidak memadai, maka karyawan tersebut untuk memicu keinginan keluar dari perusahaan dan mencari pekerjaan di perusahaan lain. Sedangkan menurut A.A. Anwar Prabu Mangkunegara (2013:83), kompensasi merupakan sesuatu yang dipertimbangkan sebagai sesuatu yang sebanding dan kempensasi yang diberikan kepada pegawai sebagai penghargaan dari pelayanan mereka. Sedangkan menurut Hadari Nawawi (2011:315) mengemukan bahwa kompensasi organisasi/perusahaan berarti penghargaan/ganjaran pada para pekerja yang telah memberikan kontribusi dalam mewujudkan tujuannya melalui kegiatan yang disebut bekerja.

Menurut Thomas H. Stone dalam bukunya Understanding personal mangement, "compensation is any form of payment to employes for work they provide their employer" kompensasi adalah setiap bentuk pembayaran yang diberikan kepada majikan. Sedangkan menurut Edwin B. Flippo dalam bukunya principles of personnal management, "compensation as the adequate and equitable remuneration of personal for their contribution to organization objektivites " dalam buku manajemen sumber daya manusia, Suwanto dan Donni Juni Priansa (2011:220)

Sedangkan menurut Ike Kudyah Rachmawati (2008:143) kompensasi merupakan hal yang kompleks dan sulit, karena didalamnya melibatkan dasar kelayakan, logika, rasional dan dapat dipertanggung jawabkan serta menyangkut faktor emosional dari aspek tenaga kerja, kompensasi diberikan dengan tujuan memberikan rangsangan dan motivasi kepada tenaga kerja untuk meningkatakan prestasi kerja serta efesien dan efektifitas produksi.

Menurut William B. Werther dan Keith Davis dalam buku Hasibuan (2004:52), Suparno Eko Widodo (2015:155), kompensasi adalah apa yang seorang pekerja terima sebagai balasan dari pekerjaan yang diberikannya, baik upah per jam maupun gaji periodik didesain dan di- 
kelola oleh bagian personalia. Sedangkan menurut Andrew F.Sikula dalam buku Hasibuan (2009:118), Suparno Eko Widodo (2015:155), kompensasi adalah segala sesuatu dikontitusikan atau dianggap sebagai suatu balas jasa ekuivalen, berdasarkan beberapa pengertian diatas, dapat disimpulkan bahwa kompensasi adalah penghargaan atau imbalan yang diterima oleh karyawan yang diberikan oleh perusahaan berdasarkan kontribusi maupun kinerja secara produktif dengan yang lebih baik pada suatu organisasi.

Menurut Siti Alfajar dan Tri Heru, kompensasi seluruh exrtinsic rewads yang diterima oleh karyawan dalam bentuk upah atau gaji, insentif dan bonus, dan beberapa tunjangan (benifits). Exrtinsic rewads, adalah imbalan yang di kontrol dan didistribusikan secara langasung oleh organisasi dan sifatnya berwujud, upah dan gaji pokok adalah pembayaran yang diterima karyawan secara bulanan, mingguan, atau setiap jam sebagai hasil pekerjaan mereka, insentif merupakan imbalan yang ditambahkan terhadap upah atau gaji dan biasanya berkaitan secara langsung dengan prestasi kerja, (seperti bonus, komis, profit sharing, dan price rate plans), sedangkan benefits adalah imbalan yang diterima karyawan sebagai hasil dari pekerjaan dan posisi mereka dalam organisasi (seperti, Pembayaran dihari libur, ausransi kesehatan, asuransi jiwa dan tunjangan pensiun), pembayaran pay adalah penerimaan karyawan secara nyata sebagai hasil dari pekerjaan mereka.

\section{Budaya Organisasi}

Menurut Umar Nimran (2013:125) budaya organisasi (organizational culture) atau budaya perusahaan (corporate culture) akhir - akhir ini sering muncul ke permukaan, dan menjadi bahan pembicaraan dan kajian, baik kalangan praktisi maupun ilmuwan. Pengembangan budaya organisasi/perusahaan, bahwa budaya organisasi atau perusahaan sangat bermanfaat dan penting bagi perkembangan organisasi atau perusahaan.
Menurut Sudaryanto (2014:9), untuk memperkaya dan pemperlua tentang pemahaman budaya peusahaan, Tika (2016), mengemukan secara konseptual menurut bebarapa para pakar dan ahli, Vijay Sathe dalam Ismail Nawawi Uha (2013), mengemukan bahwa secara umum adalah perangkat asumsi penting yang dimiliki bersama anggaota masyarakat. Robert Owen, mengemukakan budaya adalah suatu sitim pembagian nilai dan kepercayaan yang berinteraksi dengan orang dalam suatu organisasi, struktur organisasi dan sistem kontrol yang menghasilkan norma perilaku unsur-unsur yang ada dalam budaya organisasi atau perusahaan digali dari persepsi, kepercayaan, dan nilai yang ada dalam sumber daya manusia di dalam perusahaan. Budaya perusahaan merupakan aplikasi budaya organisasi (organization culture) terhadap badan usaha (Taliziduhu, 1997). Budaya perusahaan mancakup nilai nilai-nilai yang dipegang bersama, keyakinan dan sikap perilaku bersama, budaya perusahaan merumuskan cara kita mengerjakan segala sesuatu disini (Winarno, 2011).

Atau Kata budaya (culture) sebagai konsep berakar dari kajian atau disiplin ilmu antropologi; yang oleh Kilman, Saxton, \& serpa diartikan sebagai " the shared philosophies, idiologies, values, assumptions, beliefs, expectotations, attitudes, and norms that knit a community togetre "(falsafah, idiologi, nilai - nilai, anggapan, keyakinan, harapan, sikap dan norma yang dimiliki bersama dan mengikat suatu masyrakat). Perkembangan ilmu organisasi saat ini sangatlah populer baik di Amerika Serikat maupun di bagian - bagian dunia yang lain termasuk Indonesia.

Menurut Eliott Jacques, budaya perusahaan dan budaya organisasi adalah: "The customary or traditional ways of thingking and doing thing,which are shared to a greater or lesser extent by all membesr of the organization and which new number must learn and at least partially accept in order to be accepted into the servise of the firm " Sedangkan menurut Griffin \& 
Ebert, menyebutkan : "corporate culture is the shared experiences stories, belief, and norms that characterize on organization."

\section{Motivasi}

Menurut AA. Anwar Prabu Mangkunegara (2013: 93) pengertian motivasi kerja, sebagai suatu kecenderungan untuk beraktivitas dan dimulai dorongan dalam diri sendiri (drive) dan diakhiri dengan penyesuai diri. Sedangkan menurut William J. Stanton (1981:101) mendefinisikan bahwa " A Motive is a stimulated need which a goal-oriented individual seeks to satisfy" (suatu motiv adalah kebutuhan yang distimulasi yang berorientasi kepada tujuan individu dalam mencapai rasa) dan menurut Fillmore H. Standford (1969:173) bahwa "Motivation as an energizing condition of the organism that serves to direct that organism toward the goal of a certain class ( motivasi sebagai suatu kondisi yang menggerakan manusia ke arah suatu tujuan tertentu ) dalam buku manajemen sumber daya manusia AA. Anwar Prabu Mangkunegara (2013: 93)

Jadi motivasi adalah dapat diartikan sebagai dorongan yang menggerakan pribadi pegawai untuk berperan secara aktip dalam mencapai tujuan, proses timbul motivasi seseorang merupakan gabungan dari konsep kebutuhan, dorongan, tujuan dan kompensasi. Dalam hubungannya dengan lingkungan kerja, Ernest J. Mc. Cormickdalam buku AA. Anwar Prabu Mangkunegara (2013:94) mengemukan bahwa "work motivation is difened as conditions which influence the arousal, direction, and maintenance of behaviors relevant in work settings " Menurut Abraham Maslow, mengembangkan motivasi yang dikenal dengan Hierarki Kebutuhan, ia melihat kebutuhan manusia itu diatur dalam bentuk yang bertingkat - tingkat, sehingga dimulai dari kebutuhan yang rendah sampai dengan kebutuhan yang tertinggi.

Menurut Suparno Eko Widodo (2014:187), motivasi adalah kekuatan yang ada dalam seseorang yang mendorong perilakunya untuk me- lakukan tindakan, besarnya intensitas kekuatan dari dalam diri seseorang untuk melakukan tugas atau mencapai sasaran memperlihatkan sejauh mana tingkat motivasinya. Menurut teori dari Vroom (1964) dalam buku Suparmo Eko Widodo (2014:189), tinggi rendahnya motivasi seseorang ditentukan oleh tiga komponen yaitu sebagai berikut :

1. Ekspetasi (harapan) keberhasilan pada suatu tugas.

2. Instrumentalis, yaitu penilaian tentang apa yang akan terjadi jika berhasil dalam melakukan suatu tugas (keberhasilan tugas untuk mendapatkan outcome tertentu).

3. Valensi, yaitu respons terhadap outcome seperti perasaan positif, netral, atau negatif, motivasi tinggi jika usaha menghasilkan sesuatu yang melebihi harapan sedangkan motivasi rendah menghasilkan kurang dari yang diharapkan.

Sedangkan achicvement theory yang dikemukakan oleh Mc Clelland (1961) menyatakan bahwa ada tiga hal penting yang menjadi kebutuhan manusia yaitu sebagai berikut :

1. Need for achicvement (kebuatuhan akan prestasi).

2. Need for afiliation (kebutuhan akan hubungan sosial/hampir sama dengan social neednya Maslow)

3. Need for power (dorongan buat mengatur)

\section{Kinerja}

Pengertian kinerja, menurut AA. Anwar Prabu Mangkunegara (2013:67) istilah kinerja berasal dari kata job performance atau actual performance (prestasi kerja atau prestasi sesungguhnya yang dicapai oleh seseorang). Pengertian kinerja (prestasi kerja) adalah hasil karya secara kualitas dan kuantitas yang dicapai oleh seseorang pegawai dalam melaksanakan tugasnya sesuai dengan tanggung jawab yang diberikan kepadanya.

Menurut Suwanto dan Donni Junio Priansa (2011:196), Kinerja merupakan performance atau unjuk kerja dan kinerja dapa pula diarti- 
kan sebagai prestasi kerja atau pelaksanaan kerja atau hasil unjuk kerja. August W. Smith menyatakan bahwa "performance is output derives from proceses, human otherwise "Kinerja merupaka hasil dari suatu proses yang dilakukan manusia. Maier menyatakan penilaian kinerja atau prestasi sebagai suatu kesukseskan yang dihasilkan seseorang dalam melaksanakan suatu pekerjaan. Menurut pendapat Lawler and Poter menyatakan bahwa kinerja adalah " succesfull role achievement " yang diperoleh seseorang dari perbuatannya Tingkat keberhasilan seseorang dalam menyelesaikan pekerjaannya disebut istilah "level performance" atau level kinerja karyawan yang memiliki level kinerja tinggi merupakan karyawan yang produktivitasnya kerjanya tinggi, begitu juga sebaliknya karyawan yang mempunyai level kinerja tidak sesuai dengan standar yang ditetapkan, maka karyawan tersebut merupakan karyawan yang tidak produktif.

Menurut Vithzal Rivai (2009:549), penilaian kinerja mengacu pada suatu sistem formal dan terstruktur yang digunakan untuk mengukur, menilai dan dapat mempengaruhi sifat - sifat yang berkaitan dengan hasil pekerjaan, perilaku karyawan serta hasil yang dicapai, termasuk tingkat kehadiran karyawan dengan demikian penilaian kinerja dalam lingkup tanggung jawabanya.

Menurut Mathis dan Jackson (2002), mengenai permasalan kinerja karyawan maka tidak terlepas dari berbagai macam faktor yang menyertai diantaranya :

1. Faktor kemampuan (ability), secara psikologis kemampuan (ability) pegawai terdiri dari kemampuan potensi (IQ) dan kemapuan reality (knowledge) dan skill pegawai yang memiliki IQ dia atas rata-rata (110-120) dengan pendidikan yang memadai untuk jabatannya dan terampil dalam mengerjakan pekerjaan sehari-hari

2. Faktor motivasi, motivasi terbentuk sikap (attitude) seseorang atau pegawai dalam menghadapi situasi (situation) kerja, moti- vasi merupakan kondisi yang menggerakan diri pegawai yang terarah untuk mencapai tujuan kerja menurut Sedarmayanti (2007).

\section{Kerangka Pemikiran}

1. Hubungan antara kompensasi terhadap kinerja pegawai;

2. Hubungan antara budaya organisasi terhadap kinerja pegawai;

3. Hubungan Motivasi terhadap kinerja pegawai;

4. Hubungan antara kompensasi, budaya organisasi dan motivasiterhadap kinerja pegawai.

\section{Hipotesis Penelitian}

Berdasarkan teori kerja dan kerangka pemikiran tersebut di atas, hipotesis yang diajukan dalam penelitian ini adalah sebagai berikut:

1. Diduga ada pengaruh yang positif dan signifikan antara kompensasi terhadap kinerja;

2. Diduga ada pengaruh yang positif dan signifikan antara budaya organisasi terhadap kinerja;

3. Diduga ada pengaruh yang positif dan signifikan antara motivasi terhadap kinerja;

4. Diduga ada pengaruh yang positif dan signifikan antara kompensasi, budaya organisasi dan motivasi terhadap kinerja.

\section{METODELOGI PENELITIAN}

\section{Tempat dan Waktu Penelitian}

1. Tempat penelitian

Penelitian bertempat di Perusahaan Daerah Air Minum Tirta Kerta Raharja Kabupaten Tangerang, Jalan Kisamaun No. 204 Kota Tangerang - Provinsi Banten

2. Waktu Pelaksanaan

Proses waktu pelaksanaan penelitian berlangsung dilaksanakan di Perusahaan Daerah Air Minum Tirta Kerta Raharja Kabupaten Tangerang selama kurun waktu 4 bulan

\section{Jenis Penelitian}

Penelitian adalah keseluruhan proses yang dilakukan dalam penelitian guna mendapatkan data-data penelitian yang dibutuhkan dan cara 
menganalisa data penelitian sehingga dapat diperoleh informasi fakta-fakta dan prinsip-prinsip hasil penelitian dengan sabar, hati-hati serta secara sistimatis sehingga dapat menghasilkan kebenaran dan keakuratan hasil penelitian.

Penelitian ini merupakan penelitian dengan metode survei, menurut Sugiyono (2014:12) yaitu penelitian survei adalah penelitian yang dilakukan pada populasi jumlah besar maupun jumlah kecil, tetapi data yang dipelajari dari sampel yang diambil dari populasi tersebut untuk menentukan kejadian.

\section{Desain Penelitian}

Desain penelitian merupakan bagian dari perencanaan penelitian yang menunjukan untuk melihat apakah penelitian yang direncanakan telah memiliki validitas internal dan validitas eksternal yang komprehensif.

\section{Definisi Operasional Variabel}

Operasional adalah suatu definisi yang memberikan penjelasan atas suatu variabel dalam bentuk yang dapat diukur. Definisi operasional ini memberikan informasi yang diperlukan untuk mengukur variabel yang akan diteliti. Perlu diketahui bahwa definisi operasional adalah definisi yang dibuat oleh peneliti itu sendiri. Peneliti dapat dengan bebas mendefinisikannya dalam suatu pengertian yang bisa diukur.

Tabel 1.3

Difinisi Opersional Variabel

\begin{tabular}{|c|c|c|c|}
\hline Variabel & Defenisi Operasional & Indikator & Keterangan \\
\hline $\begin{array}{l}\text { Kompensasi }\left(X_{1}\right) \\
\text { T. Hani Handoko } \\
\text { (2014) }\end{array}$ & $\begin{array}{l}\text { Kompensasi adalah } \\
\text { segala sesuatu yang } \\
\text { diterima karyawan } \\
\text { sebagai balas jasa untuk } \\
\text { kerja mereka }\end{array}$ & $\begin{array}{l}\text { 1. Perusahaan tempat saya berkerja dalam memberikan gaji / } \\
\text { upah dapat memenuhi kebutuhan sehari - hari pegawai dan } \\
\text { keluarganya } \\
\text { 2. Gaji yang diberikan perusahaan saat ini sudah sesuai dengan } \\
\text { peraturan yang berlaku. } \\
\text { 3. Bonus, insentif dan tunjangan - tunjangan yang diberikan oleh } \\
\text { perusahaan sudah sesuai dengan harapan pegawai } \\
\text { 4. } \begin{array}{l}\text { Bonus, insentif dan tunjangan - tunjangan yang terima pegawai } \\
\text { untuk dapat meningkatkan kinerja perusahaan }\end{array} \\
\text { 5. Perusahaan telah memberikan fasilitas jaminan hari tua, asuransi } \\
\text { tenaga kerja, asuransi kesehatan dan fasilitas olah raga }\end{array}$ & Kuisioner \\
\hline $\begin{array}{l}\text { Budaya Organisasi } \\
\left(\mathrm{X}_{2}\right) \\
\text { Garetth R Jones } \\
(2010)\end{array}$ & $\begin{array}{l}\text { Budaya Organisasi adalah } \\
\text { suatu persepsi bersama } \\
\text { yang dianut oleh anggota } \\
\text { - anggota organisasi, } \\
\text { suatu sistim dari makna } \\
\text { bersama }\end{array}$ & $\begin{array}{l}\text { 1. Bila terjadi dalam permasalah dalam pekerjaan akan } \\
\text { mendiskusikan dengan pegawai lain untuk mencari solusi dan } \\
\text { menyelesaikannya } \\
\text { 2. Dalam bekerja saya mengutamakan kerjasama tim untuk } \\
\text { mencapai tujuan perusahaan. } \\
\text { 3. Saya memanfaatkan waktu bekerka semaksimal mungkin untuk } \\
\text { menyelesaikan } \\
\text { 4. setiap pekerjaan } \\
\text { Saya memanfaatkan fasilitas kerja yang diberikan oleh perusahaan } \\
\text { untuk dapat membantu dan menyelesaikan pekerjaann } \\
\text { 5. Perusahaan menyampai visi dan misi kepada pegawai untuk } \\
\text { pencapaian kinerja } \\
\text { 6. Perusahaan mendorong pegawai untuk melakukan inovasi, } \\
\text { gagasan dan kreatif dalam pekerjaan }\end{array}$ & Kusioner \\
\hline $\begin{array}{l}\text { Motivasi } \\
\left(\mathrm{X}_{3}\right) \\
\text { AA. Anwar Prabu } \\
\text { Mangkunegara } \\
(2013: 93)\end{array}$ & $\begin{array}{l}\text { Motivasi Kerja, sebagai } \\
\text { suatu kecenderungan } \\
\text { untuk beraktivitas } \\
\text { dan dimulai dorongan } \\
\text { dalam diri sendiri } \\
\text { (drive) dan diakhiri } \\
\text { dengan penyesuai } \\
\text { diri. Penyesuaian } \\
\text { diri dikatakan untuk } \\
\text { memuaskan motif }\end{array}$ & $\begin{array}{l}\text { 1. Pendidikan dan pelatihan pegawai dapat meningkatan } \\
\text { kemampuan dan skill untuk meningkatkan kinerja perusahaan } \\
\text { 2. Pemberian kepada pegawai yang berprestasi akan memotivasi } \\
\text { kerja untuk peningkatan kinerja perusahaan } \\
\text { 3. Hubungan yang baik antar pegawai akan menciptakan keamanan } \\
\text { 4. dan kenyaman lingkungan kerja } \\
\text { 5. Perusahaan memberikan kesempatan kepada pegawai untuk } \\
\text { 6. Tingkat kehadiran pegawai dapat meningkatkan kinerja } \\
\text { 7. Promosi jabatan yang diberikan perusahaan kepada pegawai } \\
\text { sesuai dengan kemampuan dan skill }\end{array}$ & Kusioner \\
\hline
\end{tabular}




\begin{tabular}{|c|c|c|c|}
\hline $\begin{array}{l}\text { Kinerja } \\
\text { Pegawai } \\
\text { (Y) } \\
\text { AA. Anwar Prabu } \\
\text { Mangkunegara } \\
\text { (2011) }\end{array}$ & $\begin{array}{l}\text { Kinerja, hasil karya } \\
\text { secara kualitas dan } \\
\text { kuantitas yang dicapai } \\
\text { seseorang pegawai dalam } \\
\text { melaksanakan tugasnya } \\
\text { sesuai dengan tanggung } \\
\text { jawab yang diberikan }\end{array}$ & $\begin{array}{l}\text { 1. Kinerja pegawai dapat diukur dari kualitas dan kuantias hasil } \\
\text { pekerjaan yang telah dilakukannya } \\
\text { 2. Kehadiran pegawai dapat meningkatkan kinerja pegawai dan } \\
\text { dapat mengerjakan dengan tepat waktu } \\
\text { 3. Pegawai yang terlatih dan terampil dapat meningkatkan kinerja } \\
\text { perusahaan } \\
\text { 4. Perusahaan menetapkan rencana dan terget yang ditentukan } \\
\text { 5. Pegawai dapat membina hubungan kerjasama yang harmonis } \\
\text { baik dengan pimpinan maupun sesama rekan kerja } \\
\text { 6. Fasilitas kerja yang disediakan perusahaan dapat membantu } \\
\text { pencapaian kinerja perusahaan }\end{array}$ & Kusioner \\
\hline
\end{tabular}

Tabel 1.4

Kisi-Kisi Kuesioner

\begin{tabular}{|c|c|c|c|}
\hline No & Variabel & Indikator & Butir Pernyataan \\
\hline \multirow{3}{*}{1.} & \multirow{3}{*}{ Kompensasi } & Gaji & 1,2,3, \\
\hline & & Bonus & $4,5,6,7$ \\
\hline & & Proteksi Pegawai & $8,9,10,11,12$ \\
\hline \multirow{4}{*}{2.} & \multirow{4}{*}{$\begin{array}{l}\text { Budaya } \\
\text { Organisasi }\end{array}$} & Prilaku & $1,2,3$ \\
\hline & & Visi dan Misi & $4,5,6$ \\
\hline & & Pembelajaran & $7,8,9$ \\
\hline & & Motivasi & $10,11,12$ \\
\hline \multirow{5}{*}{3.} & \multirow{5}{*}{ Motivasi } & Kemaun & 1,2 \\
\hline & & Semangat Bekerja & $3,4,5$ \\
\hline & & Keyakinan & $6,7,8$ \\
\hline & & Insentif & 9,10 \\
\hline & & Arahan Pimpinan & 11,12 \\
\hline \multirow{6}{*}{4.} & \multirow{6}{*}{ Kinerja } & Kualitas Kerja & 1,2 \\
\hline & & Kuantitas Kerja & 3,4 \\
\hline & & Kreatifitas Kerja & 5,6 \\
\hline & & Kedisiplinan & 7,8 \\
\hline & & Hubungan kerja & 9,10 \\
\hline & & Loyalitas & 11,12 \\
\hline
\end{tabular}

\section{Sumber dan Cara Pengumpulan Data}

Pengumpulan data adalah suatu proses pengumpulan data primer dan sekunder dalam suatu penelitian (Sofyan Siregar, 2013:130) bahwa pengumuplan data merupakan suatu prosedur yang sistimatis dan standar untuk memperoleh data yang diperlukan, yang selalu ada hubungan antara metode pengumpulan data dengan permasalahan penelitian.

\section{Populasi}

Populasi dari penelitian ini adalah Pegawai Perusahaan Daerah Air Minum Tirta Kerta Raharja Kabupaten Tangerang, terdiri pejabat Struktural, Fungsional dan pelaksana di seluruh jenjang pendidikan, usia dan jenis kelamin berjumlah 373 pegawai pada tahun 2015.

\section{Sampel}

Dalam hal ini, peneliti melakukan penarikan jumlah sampel penelitian dengan cara simple random sampling (sampling acak sederhana) dimana sampel dipilih secara acak dari jumlah yang telah ditentukan. Dalam penentuan jumlah sampel tersebut, peneliti menggunakan rumus perhitungan Slovin sebagai berikut :

$$
n=\frac{N}{\left(N \cdot e^{2}\right)+1}
$$

Dimana :

$\mathrm{n}=$ Ukuran sampel

$\mathrm{N}=$ Populasi

$\mathrm{e}=$ Batas toleransi kesalahan (error tolerance)

Dalam menentukan jumlah sampel yang akan dipilih, penulis menggunakan tingkat kesalahan sebesar $5 \%$, karena dalam setiap penelitian tidak mungkin hasilnya sempurna $100 \%$, semakin kecil toleransi kesalahan, semakin akurat sampel yang menggambarkan populasi. Maka sampel yang akan digunakan dalam penelitian ini sebanyak 193 orang / responden dengan melakukan penghitungan sebagai berikut:

$$
\begin{aligned}
& n=\frac{N}{\left(N \cdot e^{2}\right)+1} \\
& n=\frac{373}{\left(373 \cdot 0,0^{2}\right)+1} \\
& n=193,01 \\
& n=193
\end{aligned}
$$


Dengan demikian maka sampel yang akan digunakan untuk penelian sebanyak 193 responden sebagai sampel penelitian untukmenggambarkan keadaan seluruh populasi dimana jawaban dalam pernyataan terdiri dari 5 (lima) peringkat yang mengacu pada skala likert.

\section{Rancangan dan Analisis dan Uji Hipotesa}

1. Uji Kualitas Data

a. Uji Validitas

Validitas adalah suatu ukuran yang menunjukkan tingkat- tingkat kevalidan atau kesahihan suatu instrument menurut Arikunto (2011:116).Sedangkan menurut Imam Ghozali (2005:142) Uji Validitas digunakan untuk mengetahui sah/valid tidak suatu kuisioner, suatu kuisioner dinyatakan valid jika pertanyaan pada kuisioner mampu mengungkapkan sesuatu yang akan diukur oleh kuisioner tersebut, Validitas menunjukkan sejauh mana alat pengukur yang dipergunakan untuk mengukur apa yang diukur.

\section{b. Uji Reliabilitas}

Menurut Ghozali (2005:170) Reliabilitas berhubungan dengan masyarakat kepercayaan Reliabilitas merupakan alat untuk mengukur suatu daftar pertanyaan kuisioner yang merupakan indikator dari variabel-variabel yang diteliti. Uji reliabilitas dilakukan terhadap item pertanyaan yang dinyatakan valid.

Rumus : $\alpha=\frac{k}{k-1}\left(1-\frac{\sum S^{2} j}{S^{2} x}\right)$

2. Uji Asumsi Klasik a. Uji Normalitas

Menurut Imam Ghozali (2009: 183) caranya normal probability plot yang membandingkan distribusi komulatif dari data sesungguhnya dengan distribusi komulatif dari distribusi normal. adapun kriteria

b. Uji Heteroskedastisitas

Model regresi yang baik adalah Homoskedastisitas/ tidak Heteroskedastisitas cara untuk mendiktesikannya atau dengan cara melihat grafik perhitungan antara nilai prediksi variabel tingkat ( $z$ pred) dengan residual (srecid), analisisnya :

3. UJi Hipotesis

a. Uji Korelasi Parsial (Regresi Sederhana)

Uji korelasi parsial digunakan untuk menguji hipotesis pertama dan hipotesis kedua. Teknik korelasi parsial yang digunakan adalah korelasi pearson. Tujuan uji korelasi ini adalah untuk mengetahui hubungan antara variabel-variabel bebas dengan terikatnya.

Menurut Sugiyono (2008:182), rumus yang digunakan untuk mengetahui besarnya hubungan atau korelasi antara variabel $\mathrm{X} 1$ dan variabel $\mathrm{Y}$, serta variabel $\mathrm{X} 2$ dan variabel $\mathrm{Y}$, ini adalah dengan menggunakan rumus sebagai berikut :

$$
\mathrm{r}=\frac{\mathrm{N} \cdot \sum \mathrm{X} \cdot \mathrm{Y}-\sum \mathrm{X} \cdot \sum \mathrm{Y}}{\sqrt{\left[N\left(\sum X\right)^{2}\right] \cdot\left[N\left(\sum Y^{2}\right)-\left(\sum Y\right)^{2}\right]}}
$$

\section{b. Uji Korelasi Ganda (Regresi Berganda)}

Uji korelasi ganda digunkan untuk menguji hipotesis ketiga. Teknik korelasi ganda yang digunkan adalah korelasi pearson, tujuan uji ini adalah untuk melihat apakah terdapat korelasi berarti apabila ketiga variabel bebas secara bersama-sama dikorelasikan dengan variabel terikatnya.

Uji korelasi ganda merupakan alat untuk mengukur hubungan atau tingkat asosiasi antara variabel-variabel bebas terhadap variabel terikat secara simultan.

\section{c. Uji t ( Parsial)}

Untuk menguji variabel yang berpengaruh antara X1, X2dan X3terhadap Y secara individual (parsial) maka digunakan uji t.

Dimana untuk menentukan t hitung, penulis menggunakan rumus signifikan dari Sugiyono (2008:357), berikut rumus yang dipakai; 
$t=r \frac{\sqrt{n-2}}{\sqrt{1-r^{2}}}$

\section{d. Uji F ( Simultan)}

Untuk menguji variabel yang berpengaruh antara X1, X2 dan X3 terhadap Y secara bersama-sama (simultan) maka digunakan uji F.

Adapun kriteria pengujian uji t adalah sebagai berikut :

1. Jika Sig $<0,05$ maka Ho ditolak dan Ha diterima berarti ada pengaruh signifikan variabel independen secara simultan terhadap variabel dependen.
2. Jika Sig > 0,05 maka Ha ditolak dan Ho diterima berarti tidak ada pengaruh signifikan variabel independen secara simultan terhadap variabel dependen.

$$
\text { F hitung }=\frac{\frac{\mathrm{R}^{2}}{\mathrm{k}}}{\left[\frac{1-\mathrm{R}^{2}}{\mathrm{n}-\mathrm{k}-1}\right]}
$$

e. Koefisien Determinasi

Uji Koefisien Determinasi digunakan untuk mengetahui \% nilai Y sebagai varibel terikat yang dapat dijelaskan oleh garis regresi, Algifari (2007: 32).

rumus :

$$
\mathrm{KD}=\mathrm{r} 2 \times 100 \%
$$

(Sugiyono, 2008)

\section{HASIL PENELITIAN dan PEMBAHASAN}

\section{Uji Kualitas Data}

a. Uji Validitas

Tabel 1.5

\begin{tabular}{|c|c|c|c|c|}
\hline Variabel & Indikator & corrected item-total correlation & Batas Kritis (R-Tabel) & Keputusan \\
\hline \multirow{12}{*}{$\begin{array}{l}\text { Kompensasi } \\
\text { (X1) }\end{array}$} & X1.1 & 0.628 & 0,142 & Valid \\
\hline & $\mathrm{X} 1.2$ & 0.649 & 0,142 & Valid \\
\hline & $\mathrm{X} 1.3$ & 0.503 & 0,142 & Valid \\
\hline & $\mathrm{X} 1.4$ & 0.520 & 0,142 & Valid \\
\hline & X1.5 & 0.428 & 0,142 & Valid \\
\hline & X1.6 & 0.608 & 0,142 & Valid \\
\hline & $\mathrm{X} 1.7$ & 0.408 & 0,142 & Valid \\
\hline & X1.8 & 0.522 & 0,142 & Valid \\
\hline & X1.9 & 0.593 & 0,142 & Valid \\
\hline & $\mathrm{X} 1.10$ & 0.598 & 0,142 & Valid \\
\hline & X1.11 & 0.627 & 0,142 & Valid \\
\hline & X1.12 & 0.472 & 0,142 & Valid \\
\hline
\end{tabular}

Uji Validitas Kompensasi (Var. X1) 
Tabel 1.6

Uji Validitas Budaya Organisasi (Var. X2)

\begin{tabular}{|c|c|c|c|c|}
\hline Variabel & Indikator & corrected item-total correlation & Batas Kritis (R-Tabel) & Keputusan \\
\hline \multirow{12}{*}{$\begin{array}{l}\text { Budaya } \\
\text { Organisasi } \\
\text { (X2) }\end{array}$} & $\times 2.1$ & 0.334 & 0,142 & Valid \\
\hline & $X 2.2$ & 0.684 & 0,142 & Valid \\
\hline & $X 2.3$ & 0.642 & 0,142 & Valid \\
\hline & $X 2.4$ & 0.611 & 0,142 & Valid \\
\hline & $X 2.5$ & 0.602 & 0,142 & Valid \\
\hline & $X 2.6$ & 0.656 & 0,142 & Valid \\
\hline & $\mathrm{X} 2.7$ & 0.650 & 0,142 & Valid \\
\hline & $X 2.8$ & 0.641 & 0,142 & Valid \\
\hline & $\times 2.9$ & 0.595 & 0,142 & Valid \\
\hline & $\times 2.10$ & 0.502 & 0,142 & Valid \\
\hline & $X 2.11$ & 0.532 & 0,142 & Valid \\
\hline & $X 2.12$ & 0.660 & 0,142 & Valid \\
\hline
\end{tabular}

Tabel 1.7

Uji Validitas Motivasi (Var. X3)

\begin{tabular}{|c|c|c|c|c|}
\hline Variabel & Indikator & corrected item-total correlation & Batas Kritis (R-Tabel) & Keputusan \\
\hline \multirow{12}{*}{$\begin{array}{c}\text { Motivasi } \\
\left(X_{3}\right)\end{array}$} & X3.1 & 0.516 & 0.142 & Valid \\
\hline & $\times 3.2$ & 0.450 & 0.142 & Valid \\
\hline & X3.3 & 0.728 & 0.142 & Valid \\
\hline & X3.4 & 0.716 & 0.142 & Valid \\
\hline & $\times 3.5$ & 0.738 & 0.142 & Valid \\
\hline & X3.6 & 0.735 & 0.142 & Valid \\
\hline & $\times 3.7$ & 0.638 & 0.142 & Valid \\
\hline & X3.8 & 0.598 & 0.142 & Valid \\
\hline & X3.9 & 0.695 & 0.142 & Valid \\
\hline & X3.10 & 0.468 & 0.142 & Valid \\
\hline & X3.11 & 0.689 & 0.142 & Valid \\
\hline & X3.12 & 0.667 & 0.142 & Valid \\
\hline
\end{tabular}

Tabel 1.8

Uji Validitas Kinerja (Var. Y)

\begin{tabular}{|c|c|c|c|c|}
\hline Variabel & Indikator & corrected item-total correlation & Batas Kritis (R-Tabel) & Keputusan \\
\hline \multirow{12}{*}{$\begin{array}{c}\text { Kinerja } \\
(Y)\end{array}$} & Y.1 & 0.495 & 0.142 & Valid \\
\hline & Y.2 & 0.479 & 0.142 & Valid \\
\hline & Y.3 & 0.565 & 0.142 & Valid \\
\hline & Y.4 & 0.493 & 0.142 & Valid \\
\hline & Y.5 & 0.705 & 0.142 & Valid \\
\hline & Y.6 & 0.681 & 0.142 & Valid \\
\hline & $\mathrm{Y} .7$ & 0.723 & 0.142 & Valid \\
\hline & Y.8 & 0.770 & 0.142 & Valid \\
\hline & Y.9 & 0.661 & 0.142 & Valid \\
\hline & Y.10 & 0.640 & 0.142 & Valid \\
\hline & Y.11 & 0.576 & 0.142 & Valid \\
\hline & Y.12 & 0.697 & 0.142 & Valid \\
\hline
\end{tabular}




\section{Uji Reliabilitas}

Tabel .1.9 Uji Reliabilitas Data

\begin{tabular}{|c|c|c|c|}
\hline Variabel & $\begin{array}{c}\text { Cronbach's } \\
\text { Alpha }\end{array}$ & $\begin{array}{c}\text { N of } \\
\text { Items }\end{array}$ & $\begin{array}{c}\text { Kategori } \\
\text { Interval } \\
\text { Reliabilitas }\end{array}$ \\
\hline $\begin{array}{c}\text { Kompensasi } \\
\left(X_{1}\right)\end{array}$ & $\mathbf{0 , 7 6 8}$ & 12 & Reliabel \\
\hline $\begin{array}{c}\text { Budaya } \\
\text { Organisasi } \\
\left(X_{2}\right)\end{array}$ & $\mathbf{0 , 8 2 3}$ & 12 & $\begin{array}{c}\text { Sangat } \\
\text { Reliabel }\end{array}$ \\
\hline $\begin{array}{c}\text { Motivasi } \\
\left(X_{3}\right)\end{array}$ & $\mathbf{0 , 8 6 5}$ & 12 & $\begin{array}{c}\text { Sangat } \\
\text { Reliabel }\end{array}$ \\
\hline Kinerja $(Y)$ & $\mathbf{0 , 8 5 6}$ & 12 & $\begin{array}{c}\text { Sangat } \\
\text { Reliabel }\end{array}$ \\
\hline
\end{tabular}

Sumber : Data diolah meggunakan SPSS 21

Tabel 1.10

\section{Kriteria Penilaian Tingkat Reliabilitas}

\begin{tabular}{|l|l|}
\hline Interval & Tingkat Reliabilitas \\
\hline $0,00-0,20$ & Kurang Reliabel \\
$>0,20-0,40$ & Agak Reliabel \\
$>0,40-0,60$ & Cukup Reliabel \\
$>0,60-0,80$ & Reliabel \\
$>0,80-1,00$ & Sangat Reliabel \\
\hline
\end{tabular}

Sumber : Suyatna (2010:45)

\section{Uji Asumsi Klasik}

\section{a. Normalitas}

\section{Normal P.P Plot of Regression Standardized Residual}

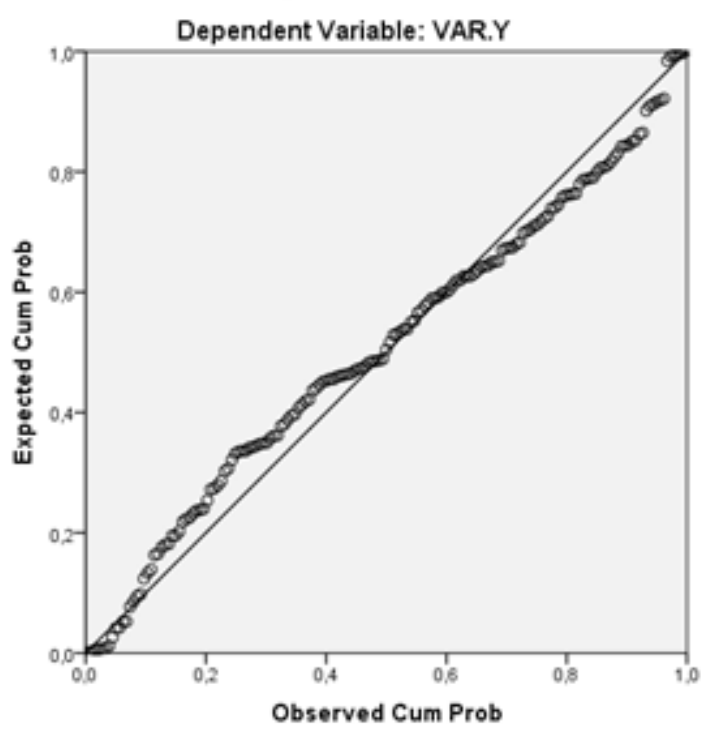

b. Uji Multikolinieritas

Tabel 1.11

\section{Coefficients Metode VIF}

\begin{tabular}{|c|c|c|c|}
\hline \multirow{2}{*}{\multicolumn{2}{|c|}{ Model }} & \multicolumn{2}{|c|}{ Collinearity Statistics } \\
\hline & & Tolerance & VIF \\
\hline \multirow{4}{*}{1} & (Constant) & & \\
\hline & VAR.X1 & ,878 & 1,139 \\
\hline & VAR.X2 & ,446 & 2,241 \\
\hline & VAR.X3 & ,455 & 2,169 \\
\hline
\end{tabular}

c. Uji Heteroskedastistas

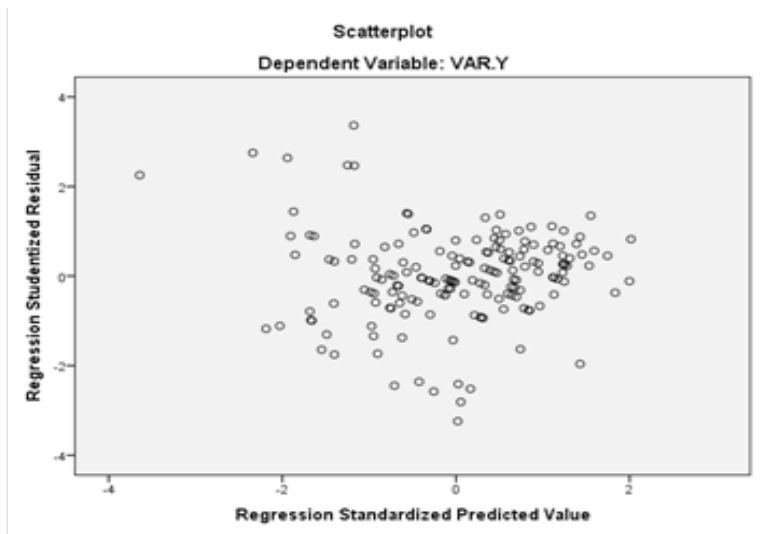

\section{Analisis Regresi}

a. Uji Signifikan Parameter Individual (Uji Statistik t)

Uji t dilakukan untuk mengetahui besarnya pengaruh masing-masing variabel independen secara individual terhadap variabel dependen. Pengujian pengaruh antara variabel kompensasi (X1) budaya organisasi (X2) Motivasi (X3) terhadap Kinerja (y) dapat dilakukan dengan uji statistik t (uji parsial). Sebagai pembanding untuk melihat pengaruh signifikan, maka digunakan kriteria taraf signifikan sebesar 5\% (0.05) dan membandingkan t-hitung dengan $t$-tabel dengan kriteria sebagai berikut:

Jika t-hitung < t-tabel berarti HO diterima dan H1 ditolak

Jika t-hitung $>$ t-tabel berarti Ho ditolak dan $\mathrm{H} 1$ diterima

Adapun ketentuan t-tabel diperoleh dengan cara jumlah responden $\mathrm{n}=193-4=1,652$ 
dilihat dari distribusi nilai $\mathrm{t}$ tabel (terlampir) maka nilai $t$ tabel 1,652

Pengaruh Kompensasi terhadap Kinerja

H0: Tidak terdapat pengaruh Kompensasi terhadap Kinerja.

H1 : Terdapat pengaruh Kompensasi terhadap Kinerja.

Adapun hasil pengolahan menggunakan program SPSS 21, pengaruhnya variabel X1 terhadap variabel y antara lain sebagai berikut :

Tabel 1.12

Uji Regresi Sederhana Kompensasi terhadap Kinerja

\section{Coefficients $^{\mathrm{a}}$}

\begin{tabular}{|c|l|c|c|c|c|c|}
\hline \multicolumn{2}{|c|}{$\begin{array}{c}\text { Model } \\
\text { B }\end{array}$} & \multicolumn{2}{|c|}{$\begin{array}{c}\text { Unstandardized } \\
\text { Coefficients }\end{array}$} & $\begin{array}{c}\text { Standardized } \\
\text { Coefficients }\end{array}$ & \multirow{2}{*}{ T } & \multirow{2}{*}{ Sig. } \\
\cline { 2 - 6 } & $\begin{array}{c}\text { Std. } \\
\text { Error }\end{array}$ & Beta & & & \\
\hline \multirow{2}{*}{1} & (Constant) & 43,825 & 1,943 & & 22,556 &, 000 \\
\cline { 2 - 6 } & VAR.X1 &, 147 &, 047 &, 220 & 3,124 &, 002 \\
\hline
\end{tabular}

Sumber : Data diolah meggunakan SPSS 21

Berdasarkan output data tabel di atas dapat diperoleh hasil sebagai berikut:

a) Model regresi yang diperoleh adalah y $=43,825+0.147 \mathrm{X} 1$

- Konstanta sebesar 43,825 menyatakan bahwa tanpa Kompensasi, Kinerja tetap terbentuk sebesar 43,825 .

- Variabel Kompensasi berpengaruh positif terhadap Kinerja dengan nilai koefisien sebesar 0.147. Artinya jika variabel Kompensasi meningkat satu satuan, maka Kinerja akan meningkat sebesar 0.147 .

b) Nilai t-hitung lebih besar dari t-tabel sebesar 3,124 > 1,652 dan taraf signifikansi t lebih kecil sebesar $0.000<$ 0.05 .

c) Dari hasil uji parsial X1-y diatas maka terjawab $\mathrm{H} 0$ ditolak dan $\mathrm{H} 1$ diterima.

d) Hal ini menunjukkan bahwa terdapat pengaruh signifikan dan positif Kompensasi terhadap Kinerja.
Tabel 1.13

\section{Uji Regresi Sederhana Budaya Organisasi terhadap Kinerja}

\begin{tabular}{|c|c|c|c|c|c|c|}
\hline & \multirow{2}{*}{$\begin{array}{c}\text { Model } \\
\text { B }\end{array}$} & \multicolumn{2}{|c|}{$\begin{array}{c}\text { Unstandardized } \\
\text { Coefficients }\end{array}$} & \multirow[t]{2}{*}{$\begin{array}{c}\text { Standardized } \\
\text { Coefficients } \\
\end{array}$} & \multirow{2}{*}{$\mathbf{T}$} & \multirow{2}{*}{ Sig. } \\
\hline & & $\begin{array}{l}\text { Std. } \\
\text { Error }\end{array}$ & Beta & & & \\
\hline \multirow{2}{*}{1} & (Constant) & 19,677 & 2,768 & & 7,106 & ,000 \\
\hline & VAR.X2 & ,615 & ,056 & 620 & 10,933 & ,000 \\
\hline
\end{tabular}

Sumber : Data diolah meggunakan SPSS 21

Berdasarkan output data tabel di atas dapat diperoleh hasil sebagai berikut:

a) Model regresi yang diperoleh adalah y $=19,677+0.615 \mathrm{X} 2$

- Konstanta sebesar 19,677 menyatakan bahwa tanpa Budaya Organisasi, Kinerja tetap terbentuk sebesar 19,677 .

- Variabel Budaya Organisasi berpengaruh positif terhadap Kinerja dengan nilai koefisien sebesar 0.615 . Artinya jika variabel Kompensasi meningkat satu satuan, maka Kinerja akan meningkat sebesar 0.615 .

b) Nilai t-hitung lebih besar dari t-tabel sebesar 10,933>1,652 dan taraf signifikansi t lebih kecil sebesar $0.000<0.05$.

c) Dari hasil uji parsial X2-y diatas maka terjawab $\mathrm{H} 0$ ditolak dan $\mathrm{H} 2$ diterima.

d) Hal ini menunjukkan bahwa terdapat pengaruh signifikan dan positif Budaya Organisasi terhadap Kinerja.

Tabel 1.14

Uji Regresi Sederhana Motivasi terhadap Kinerja

\begin{tabular}{|c|c|c|c|c|c|c|}
\hline & \multirow{2}{*}{$\begin{array}{c}\text { Model } \\
\text { B }\end{array}$} & \multicolumn{2}{|c|}{$\begin{array}{c}\text { Unstandardized } \\
\text { Coefficients }\end{array}$} & \multirow[t]{2}{*}{$\begin{array}{c}\text { Standardized } \\
\text { Coefficients }\end{array}$} & \multirow{2}{*}{$\mathbf{t}$} & \multirow{2}{*}{ Sig. } \\
\hline & & $\begin{array}{l}\text { Std. } \\
\text { Error }\end{array}$ & Beta & & & \\
\hline \multirow{2}{*}{1} & (Constant) & 21,651 & 2,392 & & 9,051 & ,000 \\
\hline & VAR.X3 & ,578 & ,049 & ,650 & 11,836 & ,000 \\
\hline
\end{tabular}


Berdasarkan output data tabel di atas dapat diperoleh hasil sebagai berikut:

a) Model regresi yang diperoleh adalah y $=21,651+0,578 \mathrm{X} 3$

- Konstanta sebesar 21,651 menyatakan bahwa tanpa Motivasi Kinerja tetap terbentuk sebesar 21,651.

- Variabel Motivasi berpengaruh positif terhadap Kinerja dengan nilai koefisien sebesar 0,578. Artinya jika variabel Motivasi meningkat satu satuan, maka Kinerja akan meningkat sebesar 0,578.

b) Nilai t-hitung lebih besar dari t-tabel sebesar 11,836 > 1,652 dan taraf signifikansi t lebih kecil sebesar $0.000<0.05$.

c) Dari hasil uji parsial X3-y diatas maka terjawab $\mathrm{H} 0$ ditolak dan $\mathrm{H} 3$ diterima.

d) Hal ini menunjukkan bahwa terdapat pengaruh signifikan dan positif Motivasi terhadap Kinerja

b. Uji Signifikan Simultan (Uji Statistik F)

Uji F dilakukan untuk mengetahui pengaruh variabel-variabel independen secara simultan (bersama-sama) terhadap variabel dependen. Hasil uji F pada output SPSS 21 dapat diliihat pada tabel ANOVA. Untuk mengetahui variabel-variabel independen secara simultan mempengaruhi variabel dependen, dilakukan dengan membandingkan p-value pada kolom Sig. Dengan tingkat signifikasi yang digunakan sebesar 0,05. Jika p-value lebih kecil dari 0,05 maka Ha diterima dan Ho ditolak, sebaliknya jika p-value lebih besar dari 0,05 maka Ha ditolak dan Ho diterima membandingkan F-hitung dengan F-tabel dengan kriteria sebagai berikut:

1) Jika F-hitung < F-tabel berarti H0 diterima dan $\mathrm{H} 4$ ditolak

2) Jika F-hitung > F-tabel berarti H0 ditolak dan $\mathrm{H} 4$ diterima

Adapun ketentuan F-tabel diperoleh dengan cara jumlah responden $\mathrm{n}=193-4=189$, dilihat dari distribusi nilai $\mathrm{F}$ tabel (terlampir) maka nilai $\mathrm{F}$ tabel 2,42
Pengaruh Kompensasi, Budaya Organisasi dan Motivasi terhadap Kinerja secara simultan (X1. X2. X3 => y)

H0: Kompensasi, Budaya Organisasi dan Motivasi tidak berpengaruh signifikan terhadap Kinerja secara simultan.

H4: Kompensasi, Budaya Organisasi dan Motivasi berpengaruh signifikan terhadap Kinerja secara simultan.

Berikut hasil pengolahan data uji signifikasi simultan uji statistik F:

Tabel 1.15

Uji Regresi Berganda Kompensasi, Budaya Organisasi dan Motivasi terhadap Kinerja

\begin{tabular}{|c|c|c|c|c|c|}
\hline \multirow{2}{*}{ Model } & \multicolumn{2}{|c|}{$\begin{array}{c}\text { Unstandardized } \\
\text { Coefficients }\end{array}$} & \multirow{2}{*}{\begin{tabular}{|c} 
Standardized \\
Coefficients
\end{tabular}} & \multirow{2}{*}{$\mathbf{t}$} & \multirow{2}{*}{ Sig. } \\
\hline & B & $\begin{array}{l}\text { Std. } \\
\text { Error }\end{array}$ & & & \\
\hline (Constant) & 16,629 & 2,714 & & 6,127 & ,000 \\
\hline VAR.X1 & ,011 & ,038 & ,017 & 292 & ,770 \\
\hline VAR.X2 & 311 & ,079 & ,313 & 3,945 & ,000 \\
\hline VAR.X3 & 378, & ,070 & ,425 & 5,405 & 000, \\
\hline
\end{tabular}

Berdasarkan output data tabel di atas dapat diperoleh hasil sebagai berikut:

Model regresi yang diperoleh adalah $\mathrm{y}=$ $16,629+0.11 \mathrm{X} 1+0,311 \mathrm{X} 2+0,379 \mathrm{X} 3$.

Konstanta sebesar 16,629 menyatakan bahwa tanpa Kompensasi, Budaya Organisasi dan Motivasi, Kinerja tetap terbentuk sebesar 16,629.

Tabel 1.16

Uji Simultan (F)

ANOVA $^{a}$

\begin{tabular}{|c|l|c|c|c|c|c|}
\hline \multicolumn{2}{|c|}{ Model } & $\begin{array}{c}\text { Sum of } \\
\text { Squares }\end{array}$ & df & $\begin{array}{c}\text { Mean } \\
\text { Square }\end{array}$ & F & Sig. \\
\hline \multirow{2}{*}{1} & Regression & 1806,650 & 3 & 602,217 & 55,289 &, $000^{b}$ \\
\cline { 2 - 7 } & Residual & 2058,635 & 189 & 10,892 & & \\
\cline { 2 - 7 } & Total & 3865,285 & 192 & & & \\
\hline
\end{tabular}

Sumber : Data diolah meggunakan SPSS 21

Berdasarkan output data tabel di atas dapat diperoleh hasil sebagai berikut :

1) Nilai F hitung lebih besar dari F-tabel 
sebesar 55,289 > 2,42 dengan signifikansi F sebesar 0,000 $<0,05$.

2) Dari hasil uji Simultan (F) diatas maka terjawab $\mathrm{H} 0$ ditolak dan $\mathrm{H} 4$ diterima.

3) Hal ini menunjukkan bahwa variabel Kompensasi, Budaya Organisasi dan Motivasi secara bersama-sama berpengaruh positif dan signifikan terhadap Kinerja.

c. Uji Koefesien Determinasi R2 Square koefisien determinasi (R2) bertujuan untuk mengetahui seberapa besar kemampuan variabel independen menjelaskan variabel dependen. Dalam output SPSS 21, koefisien determinasi terletak pada tabel Model Summary bdan tertulis Adjusted R Square.

\section{Tabel 1.17}

\section{Koefesien Determinasi Kompensasi terhadap} Kinerja

Model Summaryb

\begin{tabular}{|c|c|c|c|c|} 
Model & $\mathbf{R}$ & R Square & $\begin{array}{c}\text { Adjusted R } \\
\text { Square }\end{array}$ & $\begin{array}{c}\text { Std. Error of the } \\
\text { Estimate }\end{array}$ \\
\hline 1 &, $220^{\mathrm{a}}$ &, 049 &, 044 & 4,388 \\
\hline
\end{tabular}

Berdasarkan output data tabel di atas dapat diperoleh hasil sebagai berikut:

a) Nilai Koefisien R sebesar 0,220. Artinya korelasi Kompensasi terhadap Kinerja sebesar 0,220 . Hal ini dapat dikatakan bahwa adanya hubungan positif sebesar 0,220 antara variabel Kompensasi terhadap Kinerja.

b) Nilai Koefisien Determinasi Adjusted R Square sebesar 0,044. Data tersebut mengindikasikan bahwa Kompensasi terhadap Kinerja memberikan kontribusi sebesar $0,44 \%$. $(100 \%-0,44 \%=$ $99,56 \%)$ sisanya sebesar $99,56 \%$ dijelaskan oleh vaiabel lain diluar penelitian ini.
Tabel 1.18

\section{Koefesien Determinasi Budaya Organisasi terhadap Kinerja}

Model Summaryb

\begin{tabular}{c|c|c|c|c|} 
Model & $\mathbf{R}$ & R Square & $\begin{array}{c}\text { Adjusted R } \\
\text { Square }\end{array}$ & $\begin{array}{c}\text { Std. Error of } \\
\text { the Estimate }\end{array}$ \\
\hline 1 &, $620^{a}$ &, 385 &, 382 & 3,528 \\
\hline
\end{tabular}

Berdasarkan output data tabel di atas dapat diperoleh hasil sebagai berikut:

a) Nilai Koefisien R sebesar 0,620. Artinya korelasi Budaya Organisasi terhadap Kinerja sebesar 0,620. Hal ini dapat dikatakan bahwa adanya hubungan positif sebesar 0,620 antara variabel Budaya Organisasi terhadap Kinerja.

b) Nilai Koefisien Determinasi Adjusted $\mathrm{R}$ Square sebesar 0,382. Data tersebut mengindikasikan bahwa Budaya Organisasi terhadap Kinerja memberikan kontribusi sebesar 38,2\%, (100\% - 38,2\% $=61,8 \%)$ sisanya sebesar $61,8 \%$ dijelaskan oleh vaiabel lain diluar penelitian.

Tabel 1.19

\section{Koefesien Determinasi Motivasi terhadap Kinerja}

Model Summary ${ }^{\mathbf{b}}$
Model

Sumber : Data diolah meggunakan SPSS 21

Berdasarkan output data tabel di atas dapat diperoleh hasil sebagai berikut:

a) Nilai Koefisien $\mathrm{R}$ sebesar 0,650. Artinya korelasi Motivasi terhadap Kinerja sebesar 0,650. Hal ini dapat dikatakan bahwa adanya hubungan positif sebesar 0,650 antara variabel Motivasi terhadap Kinerja.

b) Nilai Koefisien Determinasi Adjusted $\mathrm{R}$ Square sebesar 0,420. Data tersebut mengindikasikan bahwa Motivasi terhadap Kinerja memberikan kontribusi sebesar $42 \%,(100 \%-42 \%=58 \%)$ sisa- 
nya sebesar 58\% dijelaskan oleh vaiabel lain diluar penelitian.

Tabel 1.20

Koefesien Determinasi Kompensasi, Budaya Organisasi dan Motivasi terhadap Kinerja

Model Summary
\begin{tabular}{|c|c|c|c|c|} 
Model & R & R Square & $\begin{array}{c}\text { Adjusted R } \\
\text { Square }\end{array}$ & $\begin{array}{c}\text { Std. Error of } \\
\text { the Estimate }\end{array}$ \\
\hline 1 &, $684^{\mathrm{a}}$ &, 467 &, 459 & 3,300 \\
\hline
\end{tabular}

Sumber : Data diolah meggunakan SPSS 21

Berdasarkan output data tabel di atas dapat diperoleh hasil sebagai berikut:

a) Nilai Koefisien R sebesar 0,684. Artinya korelasi Kompensasi, Budaya Organisasi dan Motivasi terhadap Kinerja sebesar 0,684 . Hal ini dapat dikatakan bahwa adanya hubungan positif sebesar 0,684 antara variabel Kompensasi, Budaya Organisasi dan Motivasi terhadap Kinerja.

b) Nilai Koefisien Determinasi Adjusted R Square sebesar 0,459. Data tersebut mengindikasikan bahwa Kompensasi, Budaya Organisasi dan Motivasi terhadap Kinerja memberikan kontribusi sebesar 45,9\%, $(100 \%-45,9 \%=54.1 \%)$ sisanya sebesar $54.1 \%$ dijelaskan oleh vaiabel lain diluar penelitian ini.

\section{Hasil Pembahasan}

Untuk mempermudah pembahasan atas analisis yang dilakukan, akan dijelaskan pengaruh dari masing-masing variabel bebas yang meliputi Kompensasi, Budaya Organisasi dan Motivasi terhadap Kinerja.

1) Pengaruh Kompensasi terhadap Kinerja. Model regresi yang diperoleh adalah y $=43,825+0.147 \mathrm{X} 1$

Konstanta sebesar 43,825 menyatakan bahwa tanpa Kompensasi, Kinerja tetap terbentuk sebesar 43,825. Variabel Kompensasi berpengaruh positif terhadap Kinerja dengan nilai koefisien sebesar 0,147. Artinya jika variabel Kompensasi meningkat satu satuan, maka Kinerja akan meningkat sebesar 0,147.
Nilai t-hitung lebih besar dari t-tabel sebesar 3,124 > 1,652 dan taraf signifikansi t lebih kecil sebesar $0.000<0.05$.

Hal ini menunjukkan bahwa terdapat pengaruh signifikan dan positif Kompensasi terhadap Kinerja.

Hasil uji parsial disimpulkan bahwa terdapat pengaruh signifikan Kompensasi terhadap Kinerja pada pegawai dan nilai Koefisien Determinasi Adjusted R Square sebesar 0,44. Data tersebut mengindikasikan bahwa Kompensasi terhadap Kinerja memberikan kontribusi sebesar 0,44\%. (100\% $0,44 \%=99,56 \%)$ sisanya sebesar $99,56 \%$ dijelaskan oleh vaiabel lain diluar penelitian ini.

2) Pengaruh Budaya Organisasi terhadap Kinerja.

Model regresi yang diperoleh adalah y $=19,677+0,615 \mathrm{X} 2$

Konstanta sebesar 19,677 menyatakan bahwa tanpa Budaya Organisasi Kinerja tetap terbentuk sebesar 19,677. Variabel Budaya Organisasi berpengaruh positif terhadap Kinerja dengan nilai koefisien sebesar 0,615 . Artinya jika variabel Budaya Organisasi meningkat satu satuan, maka Kinerja akan meningkat sebesar 0,615.

Nilai t-hitung lebih besar dari t-tabel sebesar 10,933 > 1,652 dan taraf signifikansi t lebih kecil sebesar $0.000<0.05$.

Hal ini menunjukkan bahwa terdapat pengaruh signifikan dan positif Budaya Organisasi terhadap Kinerja pegawai Perusahaan Daerah Air Minum Tirta Kerta Raharja Kabupaten Tangerang.

Nilai Koefisien Determinasi Adjusted R Square sebesar 0,679. dan nilai Koefisien Determinasi Adjusted R Square sebesar 0,382 . Data tersebut mengindikasikan bahwa Budaya Organisasi terhadap Kinerja memberikan kontribusi sebesar 38,2\%, $(100 \%-38,2 \%=61,8 \%)$ sisanya sebesar $61,8 \%$ dijelaskan oleh vaiabel lain diluar penelitian. 
3) Pengaruh Motivasi terhadap Kinerja.

Model regresi yang diperoleh adalah y $=21,651+0.578 \mathrm{X} 3$

Konstanta sebesar 21,651 menyatakan bahwa tanpa Motivasi, Kinerja tetap terbentuk sebesar 21,651.

Nilai t-hitung lebih besar dari t-tabel sebesar 11,836 > 1,652 dan taraf signifikansi t lebih kecil sebesar $0.000<0.05$.

Hal ini menunjukkan bahwa terdapat pengaruh signifikan dan positif Motivasi terhadap Kinerja pegawai Perusahaan Daerah Air Minum Tirta Kerta Raharja Kabupaten Tangerang.

Dan nilai Koefisien Determinasi Adjusted R Square sebesar 0,420. Data tersebut mengindikasikan bahwa Motivasi terhadap Kinerja memberikan kontribusi sebesar $42 \%$, $(100 \%-42 \%=58 \%)$ sisanya sebesar $58 \%$ dijelaskan oleh vaiabel lain diluar penelitian.

4) Pengaruh Kompensasi, Budaya Organisasi dan Motivasi terhadap Kinerja.

Model regresi yang diperoleh adalah y $=16,629+0,11 \mathrm{X} 1+0,311 \mathrm{X} 2+0,378 \mathrm{X} 3$

Konstanta sebesar 16,629 menyatakan bahwa tanpa Kompensasi, Budaya Organisasi dan Motivasi Kinerja tetap terbentuk sebesar 16,629.

Nilai F-hitung lebih besar dari F-tabel sebesar 55,289 > 2,42 dan taraf signifikansi F lebih kecil sebesar $0.000<0.05$.

Hal ini menunjukkan bahwa terdapat pengaruh signifikan dan positif Kompensasi, Budaya Organisasi dan Motivasi terhadap Kinerja pegawai Perusahaan Daerah Air Minum Tirta Kerta Raharja Kabupaten Tangerang. Dan nilai Koefisien Determinasi Adjusted R Square sebesar 0,459. Data tersebut mengindikasikan bahwa Kompensasi, Budaya Organisasi dan Motivasi terhadap Kinerja memberikan kontribusi sebesar $45,9 \%,(100 \%-45,9 \%=54.1 \%)$ sisanya sebesar $54.1 \%$ dijelaskan oleh vaiabel lain diluar penelitian ini.

\section{KESIMPULAN DAN SARAN}

\section{Kesimpulan}

Berdasarkan hasil penelitian pada Perusahaan Daerah Air Minum Tirta Kerta Raharja Kabupaten Tangerang, maka dapat diambil kesimpulan sebagai berikut :

1. Kompensasi terhadap Kinerja di lingkungan Perusahaan Daerah Air Minum Tirta Kerta Raharja Kabupaten Tangerang, berdasarkan dari hasil uji parsial t terjawab bahwa Kompensasi berpengaruh positif terhadap kinerja pegawai Perusahaan Daerah Air Minum Tirta Kerta Raharja Kabupaten Tangerang.

2. Budaya Organisasi terhadap Kinerja di lingkungan Perusahaan Daerah Air Minum Tirta Kerta Raharja Kabupaten Tangerang, berdasarkan dari hasil uji parsial terjawab bahwa Budaya Organisasi berpengaruh positif terhadap kinerja pegawai Perusahaan Daerah Air Minum Tirta Kerta Raharja Kabupaten Tangerang.

3. Motivasi terhadap Kinerja di lingkungan Perusahaan Daerah Air Minum Tirta Kerta Raharja Kabupaten Tangerang, berdasarkan dari hasil uji parsial terjawab bahwa Motivasi berpengaruh positif terhadap kinerja pegawai Perusahaan Daerah Air Minum Tirta Kerta Raharja Kabupaten Tangerang.

4. Kompensasi, Budaya Organisasi dan Motivasi terhadap Kinerja di lingkungan Perusahaan Daerah Air Minum Tirta Kerta Raharja Kabupaten Tangerang, berdasarkan dari hasil uji simultan terjawab bahwa Kompensasi, Budaya Organisasi dan Motivasi berpengaruh positif secara simultan terhadap kinerja pegawai Perusahaan Daerah Air Minum Tirta Kerta Raharja Kabupaten Tangerang.

\section{Saran}

Berdasarkan hasil penelitian ini disampaikan kepada obyek penelitian yaitu Perusahaan Daerah Air Minum Tirta Kerta Raharja Kabupaten Tangerang adalah sebagai berikut : 
1. Indikator gaji pokok, tunjangan anak dan proteksi kesehatan pegawai harus diperhatikan oleh Perusahaan Daerah Air Minum Tirta Kerta Raharja Kabupaten Tangerang.

2. Perusahaan Daerah Air Minum Tirta Kerta Raharja Kabupaten Tangerang harus memperhatikan kepada para pemimpin unit kerja supaya dapat mencerminkan sikap dan prilaku yang baik dan patut menjadi contoh para bawahannya.

3. Perusahaan Daerah Air Minum Tirta Kerta Raharja Kabupaten Tangerang harus memperhatikan gaji dan tunjangan serta pendidikan dan pelatihan untuk pengambangan karier pegawai.

4. Pegawai harus berkreatifitas dan mempunyai tanggung jawab mengerjakan pekerjaan dengan tepat waktu dan cepat untuk peningkatan kinerja Perusahaan Daerah Air Minum Tirta Kerta Raharja Kabupaten Tangerang.

\section{DAFTAR PUSTAKA}

AA. Anwar Prabu \Mangkunegara, 2013. Manajemen Sumber Daya Manusia Edisi.11 Penerbit.PT. Remaja Rosdakarya. Bandung.

Arikunto S, 2002, Metode Research, Penerbit Rajawali Jakarta

Amin Kunefi Elfachmi 2011, Evaluasi Kinerja Karyawan, Penerbit LTSM Malang

Abdurahmmat Fhatoni 2006, Manajemen Sumber Daya Manusia, Penerbit Rineka Bandung

Erna Novitasari 2017, Pengantar Manajemen. Penerbit. Quadrant Yogyakarta

Ghozali 2005, Analisis Multivariant dengan Program SPSS, Undip Semarang

Hasibuan S.P. Malayu, Manajemen Sumber Daya Manusia Edisi 18 Revisi Penerbit Bumi Aksara Jakarta

Hadari Nawawi, 2011. Manajemen Sumber Daya Manusia Edisi. 8 Penerbit Gajahmada University Press. Yogjakarta.

Ike Kusdyah Rachmawati. 2007. Manajemen Sumber Daya Manusia. Penerbit CV. Andi Offset. Yogjakarta.
Kadarisman M, 2013. Manajemen Pengembangan Sumber Daya Manusia Edisi.3 Penerbit. Raja Grafindo Persada. Jakarta.

MS. Suwarto, 2014. Manajemen Kinerja Edisi.5. Penerbit. Cahaya Atma Pusaka. Yogjakarta.

Nimran Umar, 2013. Perilaku Organisasi Edisi. 2. Penerbit. Laros. Sidoarjo.

Rachmawati Ike Kusdyah. 2007. Manajemen Sumber Daya Manusia. Penerbit CV. Andi Offset. Yogjakarta.

Rivai, Veithzal. 2009. Manajemen Sumber Daya ManusiaUntuk Perusahaan. PT Raja Grafindo Persada Jakara

Suwarto, Priansa Juni Donni , 2011 Manajemen SDM Dalam Organisasi Dan Bisnis Edisi 2 Penerbit. Alfabeta. Bandung.

Sunyoto, Danang. 2013 Teori, Kuisioner, Dan Analisis Data Sumber Daya Manusia, Penerbit CAPS Yogjakarta

Sudaryono 2014, Budaya dan Perilaku Organisasi. Edisi 1 Penerbit LIC Jakarta

Siti Al Fajar dan Tri Heru i 2015, Manajemen Sumber Daya Manusia. Edisi 3 Penerbit. Sekolah Tinggi Ilmu Manajemen (YKPN) Yogjakarta.

Soekidjo Notoatmojo 2015, Pengembangan Sumber Daya Manusia Edisi 5 Penerbit PT. Rineka Cipta Jakarta.

Sedarmayanti 2010, Manajemen Sumber Daya Manusia Reformasi Birokrasi dan Manajemen pegawai Negeri Sipil, Edisi Keempat Penerbit Refika Aditama Bandung.

Sondang P Siagian 2003, Manajemen Sumber Daya Manusia Peneribit Bumi Aksara Jakarta.

Sulistiyani 2003, Manajemen Sumber Daya Manusia, Edisi 1 Penerbit Graha Ilmu Yogjakarta.

Sutrisno. E 2012, Sumber Daya Manusia penerbit Gramedia Surabaya

Sugiono 2012, Metode Penelitian Kuantatif Kualitatif dan $R$ \& $D$, Penerbit, Alfabeta Bandung.

Suparno Eko Widodo 2015, Manajemen Pengembangan Sumber Daya Manusia. Edisi 2 Penerbit Pustaka Pelajar Yogjakarta 